\title{
Morphological, biochemical, and molecular characterization of Meloidogyne spp. populations from Brazilian soybean production regions
}

\section{Camilla Martins de Oliveira $^{1^{*}}$ Ismail Teodoro Souza Junior ${ }^{2}$ Jerônimo Vieira de Araújo Filho ${ }^{2}$ Marcos Augusto de Freitas $^{3}$ Mara Rúbia da Rocha ${ }^{1}$ Silvana Petrofeza ${ }^{2}$}

${ }^{1}$ Laboratório de Nematologia, Universidade Federal de Goiás (UFG), 74690-900, Goiânia, GO, Brasil.

E-mail: camillam.08@gmail.com. "Corresponding author.

${ }^{2}$ Laboratório de Biologia Molecular de Fungos, Universidade Federal de Goiás (UFG), Goiânia, GO, Brasil.

${ }^{3}$ JEM Análise Agrícola, Aparecida de Goiânia, GO, Brasil.

\begin{abstract}
Soybean is a commodity of great economic importance worldwide, particularly in Brazil, world's second largest producer. Nematodes, especially those of the Meloidogyne genus, severely limit productivity. Identification of nematode species is important for effective soybean management. Here, 26 populations of root-knot nematode (Meloidogyne spp.) from 15 municipalities in the states of Bahia, Mato Grosso, Goias, and Minas Gerais were characterized based on the morphology of the female perineal region, esterase profile, and identification based on amplification of specific regions of the population genome. Among the Meloidogyne spp. populations obtained, M. incognita and M. javanica, were identified. No mixed populations were present in the samples. Diagnosis based on molecular analysis was shown to be reliable and the fastest for characterization of nematode populations compared to other methods analyzed.

Key words: root-knot nematode, Glycine max, esterase, molecular identification.
\end{abstract}

Caracterização morfológica, bioquímica e molecular de populações de Meloidogyne spp. de regiões brasileiras produtoras de soja

RESUMO: A soja é uma commodity de grande importância econômica em todo mundo, especialmente no Brasil, segundo maior produtor mundial. Os nematoides, em especial os do gênero Meloidogyne, causam grandes limitações na produtividade. A identificação das espécies de nematoides é uma informação importante para o manejo adequado. Neste trabalho, 26 populações do nematoide das galhas (Meloidogyne spp.), provenientes de municípios do estado da Bahia, Mato Grosso, Goiás e de Minas Gerais, foram caracterizados com base na morfologia da região perineal das fêmeas de Meloidogyne spp., seu perfil de esterase e identificação baseada em amplificação de regiões especificas do genoma dessas populações. Entre as populações de Meloidogyne spp. obtidas, identificou-se M. incognita e M. javanica. Não houve presença de populações mistas nas amostras analisadas. O diagnóstico baseado em análise molecular se mostrou mais rápido e confiável comparado ás outras análises.

Palavras-chave: nematoide das galhas, Glycine max, esterase, identificação molecular.

Soybean production (Glycine max L.) in Brazil is an economic activity that has presented significant growth over the last decades, being a very important socio-economic crop in Brazil and globally. However, diseases are a constant concern, considering the economic losses they can cause. Soybean hosts more than fifty genera of parasitic plant nematodes, accounting for up to a $30 \%$ loss production, and in some cases may even compromise the entire production (DIAS et al., 2010).

The identification of Meloidogyne spp. presents major challenges for the diagnostician. For an extended time, nematology laboratories have identified the root-knot nematode primarily by the configuration of the female perineal pattern. Recently, new tools for identification have become increasingly appealing for species identification, considering their low costs, less required-time, and high accuracy (OLIVEIRA et al., 2011).

Identification of nematodes at the species level is important for improved field crop management, and molecular analysis represents a major advance in nematology that may lead to a more sustainable method for controlling nematodes 
in Brazilian agriculture. Thus, the aim of the present study was to identify the species of Meloidogyne spp. through the morphology of the female perineal region, characterization of the esterase profile, and amplification of specific DNA regions in samples from different soybean-producing areas in Brazil.

Soil and soybean root samples infected with root-knot nematodes were collected from August to December, 2013, in four Brazilian states: 1) Goias (GO), 2) Mato Grosso (MT), 3) Bahia (BA) and 4) Minas Gerais (MG), totaling 15 municipalities (Table 1). These locations were chosen due to the high level of nematode infestations. The nematode populations obtained from the samples were multiplied and maintained on tomato plants (Solanum lycopersicum L., Santa Cruz group cv. Santa Clara) in pots filled with sterilized soil, under greenhouse conditions (temperature $21-30^{\circ} \mathrm{C}$ ).

Perineal cuts were performed according to the methodology of TAYLOR \& NETSCHER (1974) and mounted on slides with cover slips for observation under an optical microscope (100x magnification). Determination of the esterase profile was made according to CARNEIRO \& ALMEIDA (2001), using one female per sample. The extraction of the nematodes from the infected roots was conducted as described by COOLEN \& D'HERDE (1972), obtaining a pool of nematodes after removal of excess water. These nematodes were used for the extraction of the genomic DNA using the cetyltrimethylammonium bromide (CTAB) method as described by ZOLAN \& PUKILLA (1986).

The DNA samples from each isolate were submitted to the amplification reaction in a final volume of $30 \mu \mathrm{L}$ containing: Buffer Taq DNA polymerase 1X, $\quad 1.5 \mathrm{mM} \quad \mathrm{MgCl}_{2}, \quad 0.2 \mu \mathrm{M}$ deoxynucleotides (dNTPs), $\quad 0.2 \mu \mathrm{M}$ specific oligonucleotides, 5U of the Taq DNA polymerase enzyme (Invitrogen Corp., Carlsbad, CA, USA), and 10ng of DNA. Reaction conditions used were: $96^{\circ} \mathrm{C}$ for $2 \mathrm{~min}, 35$ cycles of $93^{\circ} \mathrm{C}$ for $1.5 \mathrm{~min}, 65^{\circ} \mathrm{C}$ for $1 \mathrm{~min}, 72^{\circ} \mathrm{C}$ for $1.5 \mathrm{~min}$, and a final extension of $72^{\circ} \mathrm{C}$ for $5 \mathrm{~min}$.

Table 1 - Populations of Meloidogyne spp. and their esterase phenotypes diagnosed from soybean root samples collected in 15 municipalities of Brazil in the states of Goiás (GO), Mato Grosso (MT), Minas Gerais (MG), and Bahia (BA).

\begin{tabular}{|c|c|c|c|}
\hline Municipalities - State - Latitude - Longitude & Morphological analysis & Esterase Phenotype & Molecular analysis \\
\hline 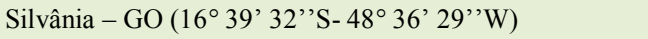 & M. incognita & I1 & M. incognita \\
\hline 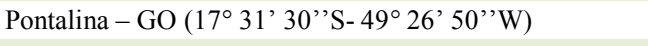 & M. incognita & I1 & M. incognita \\
\hline 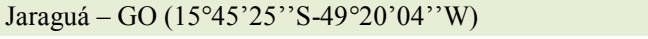 & M. incognita & I1 & M. incognita \\
\hline 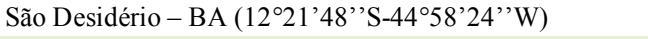 & M. incognita & I1 & M. incognita \\
\hline 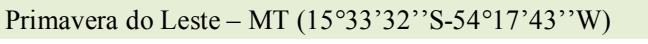 & M. incognita & I1 & M. incognita \\
\hline 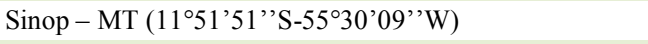 & M. incognita & I1 & M. incognita \\
\hline 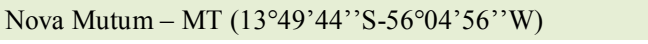 & M. incognita & I1 & M. incognita \\
\hline 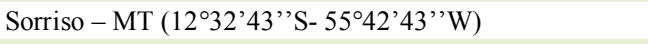 & M. incognita & I1 & M. incognita \\
\hline Cabeceiras - GO (1548'02'’S-46 $\left.55^{\prime} 36^{\prime \prime} \mathrm{W}\right)$ & M. javanica & $\mathrm{J} 2$ & M. javanica \\
\hline 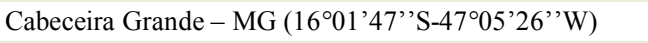 & M. javanica & $\mathrm{J} 3$ & M. javanica \\
\hline 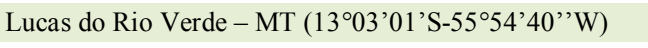 & M. javanica & $\mathrm{J} 3$ & M. javanica \\
\hline 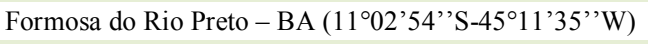 & M. javanica & $\mathrm{J} 3$ & M. javanica \\
\hline 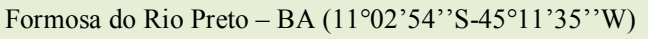 & M. javanica & $\mathrm{J} 3$ & M. javanica \\
\hline Formosa do Rio Preto - BA $\left(11^{\circ} 02^{\prime} 54^{\prime \prime} \mathrm{S}-45^{\circ} 11^{\prime} 35^{\prime \prime} \mathrm{W}\right)$ & M. javanica & $\mathrm{J} 3$ & M. javanica \\
\hline Formosa do Rio Preto - BA $\left(11^{\circ} 02^{\prime} 54^{\prime \prime} \mathrm{S}-45^{\circ} 11^{\prime} 35^{\prime \prime} \mathrm{W}\right)$ & M. javanica & $\mathrm{J} 3$ & M. javanica \\
\hline Luis E. Magalhães - BA $\left(12^{\circ} 05^{\prime} 58^{\prime}{ }^{\prime} \mathrm{S}-45^{\circ} 47^{\prime} 54^{\prime \prime} \mathrm{W}\right)$ & M. javanica & $\mathrm{J} 3$ & M. javanica \\
\hline Luis E. Magalhães - BA $\left(12^{\circ} 05^{\prime} 58^{\prime \prime} \mathrm{S}-45^{\circ} 47^{\prime} 54^{\prime \prime} \mathrm{W}\right)$ & M. javanica & $\mathrm{J} 3$ & M. javanica \\
\hline Luis E. Magalhães - BA $\left(12^{\circ} 05^{\prime} 58^{\prime \prime} \mathrm{S}-45^{\circ} 47^{\prime} 54^{\prime \prime} \mathrm{W}\right)$ & M. javanica & $\mathrm{J} 3$ & M. javanica \\
\hline Luis E. Magalhães - BA $\left(12^{\circ} 05^{\prime} 58^{\prime}{ }^{\prime} \mathrm{S}-45^{\circ} 47^{\prime} 54^{\prime \prime} \mathrm{W}\right)$ & M. javanica & $\mathrm{J} 3$ & M. javanica \\
\hline 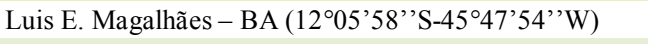 & M. javanica & $\mathrm{J} 3$ & M. javanica \\
\hline Correntina - BA $\left(13^{\circ} 20^{\prime} 36^{\prime \prime} \mathrm{S}-44^{\circ} 38^{\prime} 12^{\prime \prime} \mathrm{W}\right)$ & M. javanica & $\mathrm{J} 2$ & M. javanica \\
\hline 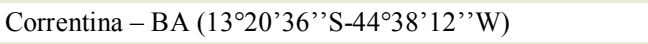 & M. javanica & $\mathrm{J} 2$ & M. javanica \\
\hline 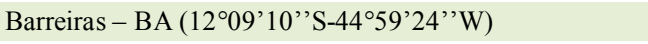 & M. javanica & $\mathrm{J} 3$ & M. javanica \\
\hline Barreiras - BA $\left(12^{\circ} 09^{\prime} 10^{\prime \prime} \mathrm{S}-44^{\circ} 59^{\prime} 24^{\prime \prime} \mathrm{W}\right)$ & M. javanica & $\mathrm{J} 3$ & M. javanica \\
\hline 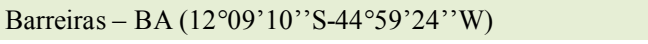 & M. javanica & $\mathrm{J} 3$ & M. javanica \\
\hline Barreiras - BA $\left(12^{\circ} 09^{\prime} 10^{\prime \prime} \mathrm{S}-44^{\circ} 59^{\prime} 24^{\prime \prime} \mathrm{W}\right)$ & M. javanica & $\mathrm{J} 3$ & M. javanica \\
\hline
\end{tabular}

Ciência Rural, v.47, n.5, 2017. 
The polymerase chain reaction (PCR) products were analyzed by electrophoresis using a $0.8 \%$ agarose gel. The oligonucleotides used for this reaction were incK14-F (5'GGGATGTGTAAATGCTCCTG3') and inc-K14-R (5'CCCGCTACACCCTCAACTTC3') (RANDIG et al., 2002) for M. incognita and Fjav (5'GGTGCGCGATTGAACTGAGC3') and Rjav (5'CAGGCCCTTCAGTGGAACTATAC3') for $M$. javanica (ZIJLSTRA et al., 2000).

The analysis allowed the identification of $M$. incognita in three samples from Goias, four samples from Mato Grosso, and one sample from Bahia. We also identified isolates of $M$. javanica in one sample from Minas Gerais, one sample from Goias, one sample from Mato Grosso, and fifteen samples from Bahia. Many studies have identified these nematode species as important parasitic nematodes in soybean crops over the last few years (CASTRO et al., 2003; DIAS et al., 2010).

$M$. javanica was prevalent in all samples, whereas $M$. incognita presented a lower occurrence, being predominant in the state of Mato Grosso (99\% of samples). All isolates from different samples presented the standard perineal patterns of $M$. incognita and $M$. javanica, with variations such as a high and very elongated labial region. Thus, to obtain results of high confidence, ten female cuts from each population were made.

The analysis of the isoenzyme profile of the esterase enzyme showed the typical phenotype of $M$. incognita (I1) in eight samples. For M. javanica, two phenotypes (J2 and J3) were observed in 18 samples. Most samples of the M. javanica populations presented a single esterase phenotype (J3), similar to the results reported by CARNEIRO et al. (1996). In the present study, 18 populations $(69.23 \%)$ of $M$. javanica were diagnosed with the phenotypes $\mathrm{J} 3$ and $\mathrm{J} 2$ and eight populations $(30.77 \%)$ of $M$. incognita with the phenotype I1. The I2 phenotype of $M$. incognita was not observed in the analyzed samples. As observed in the present study, CASTRO et al. (2003) also verified a major occurrence of $M$. javanica in soybean areas.

Analysis using the oligonucleotide indicators confirmed the detection of $M$. incognita and $M$. javanica. According to RANDIG et al. (2002) and ZIJLSTRA et al. (2000), the identification of individual nematode species in populations based on these markers has shown high efficiency and specificity, amplifying the expected fragments for $M$. incognita with $399 \mathrm{pb}$ and for M. javanica with $670 \mathrm{pb}$.

The three methods of nematode identification obtained identical results for each sample. However, although the method using the female perineal cut remains a useful tool within nematology laboratories and has the advantage of being less costly, this method may lead to errors (SILVA et al., 2014) because some nematode species, such as M. incognita, $M$. arenaria, and M. enterolobii, present similar morphological characteristics (SILVA et al., 2014). Certain limitations have also been associated with biochemical analysis, such as the absence of enzymatic patterns for all the species of Meloidogyne spp. and the dependence on the nematode development phase (BLOK \& POWERS, 2009). However, compared to the perineal cut method, the esterase profile can be considered a more accurate and faster method.

The molecular analysis based on amplification of specific genome regions stands out among the methods tested because of its speed and accuracy, particularly in the case of identifying morphologically similar nematode species or a mixture of species in the samples. The molecular method is also very useful for routine analysis in nematology laboratories, allowing a large number of samples to be processed simultaneously, thereby allowing results to be obtained within one day. Methods of species identification may assist in the improvement of nematode field control practices in conjunction with resistant cultivars, crop rotation, and other forms of control that depend on the correct identification of parasitic nematode species.

\section{ACKNOWLEDGEMENTS}

To the Conselho Nacional de Desenvolvimento Científico e Tecnológico (CNPq) for granting the scholarship for the first author Camilla Martins de Oliveira.

\section{REFERENCES}

BLOK, V.C.; POWERS, T.O. Biochemical and molecular identification. In: PERRY, R.N. et al. Root-knot nematodes. Massachusetts: CABI, 2009. p.98-112.

CARNEIRO, R.M.D.G. et al. Enzyme phenotypes of Brazilian populations of Meloidogyne spp. Fundamental and applied Nematology, v.19, n.6, p.555-560, 1996. Available from: $<$ http://horizon.documentation.ird.fr/exl-doc/pleins_textes/ fan/010007637.pdf>. Accessed: Jul. 30, 2014.

CARNEIRO, R.M.D.; ALMEIDA, M.R.A. Electrophoretic technique used in the study of root-knot nematode enzymes for species identification. Nematologia Brasileira, v.25, p.3544, 2001. Available from: <http://docentes.esalq.usp.br/sbn/ nbonline/ol\%20251/35-44\%20gr.pdf>. Accessed: May 02, 2013.

CASTRO, J.M.C. et al. Isoenzymatic variability in Brazilian populations of Meloidogyne spp. from soybean. Nematologia 
Brasileira, v.27, n.1, p.1-12, 2003. Available from: <http:// docentes.esalq.usp.br/sbn/nbonline/ol\%20271/1-12\%20pb.pdf>. Accessed: Jan. 12, 2014.

COOLEN, W.A.; D'HERDE, C.J. A method for the quantitative extraction of nematodes from plant tissue. Ghent: Nematology and Entomology Research Station, 1972. 77p.

DIAS, W.P. et al. Reaction of soybean genotypes to Meloidogyne enterolobii and M. ethiopica. Nematologia Brasileira, v.34, n.4, p.220-225, 2010. Available from: <http://docentes.esalq. usp.br/sbn/nbonline/ol\%20344/220-225\%20co.pdf>. Accessed: May 02, 2013.

OLIVEIRA, D.S. et al. Characterization of Meloidogyne incognita populations from São Paulo and Minas Gerais state and their pathogenicity on coffee plants. Tropical Plant Pathology, v.36, n.3, p.190-194, 2011. Available from: <http://www.scielo.br/pdf/ tpp/v36n3/08.pdf >. Accessed: Mar. 16, 2014.

RANDIG, O. et al. Genetic diversity of root-knot nematodes from Brazil and development of SCAR markers specific for the coffeedamaging species. Genome, v.45, p.862-870, 2002. Available from: <https://www.ncbi.nlm.nih.gov/pubmed/12416618>. Accessed: May 02, 2013.

SILVA, J.C.O. et al. General aspects and management of Meloidogyne enterolobii. In: NEFIT. (Org.). São Carlos, SP: Suprema, 2014. V.1, p.59-74.

TAYLOR, A.L.; NETSCHER, C. An improved technique for preparing perineal patterns of Meloidogyne spp. Nematologica, v.20, p.268-269, 1974. Available from: <http://horizon. documentation.ird.fr/exl-doc/pleins textes/pleins textes $5 / \mathrm{b}$ fdi_06-07/08288.pdf>. Accessed: May 02, 2013.

ZIJLSTRA. C. et al. Identification of Meloidogyne incognita, M. javanica and $M$. arenaria using sequence characterized amplified region (SCAR) based PCR assays. Nematology, v.2, n.8, p.847-853, 2000. Available from: $<$ http://horizon.documentation.ird.fr/exl-doc/pleins_textes/pleins_ textes_7/b_fdi_57-58/010024959.pdf >. Accessed: Nov. 20, 2014.

ZOLAN, M.E.; PUKILLA, P.J. Inheritance of DNA methylation in Coprinus cinerus. Molecular and Cellular Biology, v.6, p.195200, 1986. Available from: <https://www.ncbi.nlm.nih.gov/pmc/ articles/PMC367498/>. Accessed: May 02, 2013. 